\title{
A prospective study of xenon arc photocoagulation for central retinal vein occlusion
}

\author{
DONALD R. MAY, MICHAEL L. KLEIN, AND GHOLAM A. PEYMAN \\ From the Department of Ophthalmology, University of Illinois Eye and Ear Infirmary, Chicago, Illinois.
}

The clinical symptoms of central retinal vein occlusion have been recognized for the past century. The disease was first described in 1855 (Liebreich, I 855), just five years after Helmholtz invented the ophthalmoscope. There have been many subsequent studies on its natural history and pathogenesis (Klien, I953; Hayreh, I97I; Vannas and Raitta, I972).

The treatment of central retinal vein occlusion has been controversial with a myriad of therapeutic modalities producing varying results in different hands. Therapeutic regimens including potassium iodide and pilocarpine (Braendstrup, 1950), irradiation (Gradle, 1937; Benedict, I948; Hessberg, I944), anticoagulants (Holmin and Polman, 1938; Klien and Olwin, 1956; Vannas and Orma, 1957), fibrinolytic agents (Dolenek, Blatny, and Navratil, 1 968; den Ottolander, 1968), dextran 40 (François and Verbracken, 1974), corticosteroids (van Loon, I 96I; Mehlan, Eichler, and Jenssen, 1974), and carbogen (95 per cent $\mathrm{O}_{2}, 5$ per cent $\mathrm{CO}_{2}$ ) (Sedney, 1976) have been advocated.

There have been reports of good results obtained with the use of photocoagulation in branch vein occlusion (Krill, Archer, and Newell, I97I; Campbell and Wise, 1973; Gitter, Cohen, and Baber, 1975) and diabetic retinopathy (Diabetic Retinopathy Study Group, 1976). Recently, reports of photocoagulation for central vein occlusion (François, Cambie, and De Lacy, 1974; Freyler and Nichorlis, 1974; Theodossiadis, Charamis, and Velissaropoulos, 1974; Wetzig and Thatcher, 1974; Zweng, Fahrenbrush, and Little, 1974; Oosterhuis and Sedney, 1975; Sedney, 1976) have also shown good results. To our knowledge there have been no previous controlled prospective studies.

This paper is a preliminary report on the first 20 patients in a prospective controlled study initiated

This project was supported in part by a University of Illinois General Research Support Grant

Presented at the Association for Research in Vision and Ophthalmology spring meeting, Sarasota, Florida, 26-30 April, 1976

Address for reprints: Donald R. May, MD, 1855 W. Taylor Street, Chicago, Illinois 60612, USA three years ago by two of us (MLK and GAP) to evaluate the effect of xenon photocoagulation on central retinal vein occlusion.

\section{Materials and methods}

Patients over 40 years of age with central retinal vein occlusion and a visual acuity of $20 / 40$ or less were referred to us from both the clinic and private patient populations. The purpose and nature of the study were explained to the patients. Patients being treated with medications such as anticoagulants, corticosteroids, or vasodilators specifically for the central vein occlusion were not included in the study. Patients with ocular diseases (for example, diabetic retinopathy) which could influence visual acuity and those whose ocular media were not clear enough to permit photocoagulation were also excluded.

A thorough medical history was taken and then each patient was referred to the Department of Medicine at the University of Illinois Medical Center for a thorough examination. All patients underwent laboratory tests including at least: a complete blood cell count, urine analysis, three-hour glucose tolerance test, plasma thromboplastin, partial thromboplastin time, haemoglobin electrophoresis, serum protein electrophoresis, electrccardiogram, chest $x$-ray, red blood cell sedimentation rate, and serum cholesterol and triglycerides.

A complete ophthalmological examination was performed including the following: visual acuity (Snellen chart, refracted), slit-lamp examination of the anterior segment, gonioscopy and fundus biomicroscopy, applanation tonometry, visual fields (Goldmann), fundus and iris fluorescein angiography, stereoscopic colour pictures of the fundus, and electroretinography.

The patients were randomly assigned to the treatment or non-treatment group by drawing pieces of paper labelled 'treat' or 'non-treat' from a bag. Those in the non-treatment group were given no therapy for the central vein occlusion and were followed-up every three months. Patients in the other group were treated as outpatients and given photocoagulation with the Zeiss xenon photocoagulator using a Fankhauser slitlamp delivery system.

Topical 0.5 per cent tetracaine and retrobulbar 2 per cent lignocaine with epinephrine I : 100000 and hyaluronidase were given before treatment. Through dilated pupils, an average of 214 lesions $\left(3^{\circ}\right.$ centrally; all others $\left.4.5^{\circ}\right)$ with an average total energy delivery of 
I69 joules were delivered as a $360^{\circ}$ scatter photocoagulation in one treatment session. The lesions were placed at least $3^{\circ}$ apart with no lesions placed within one disc diameter of the disc or fovea. In addition, focal treatment was applied to neovascularization from the retina (NVE) when present. Neovascularization from the disc (NVD) was not treated directly. A polymyxin B-bacitracin-neomycin ointment and an eye patch were applied to the eye after treatment and the patient was examined the next day, then every week for one month, and finally at three-monthly intervals.

Eleven of the 20 patients initially admitted to the study were randomly assigned to the non-treatment group and nine were treated. Table I shows the random allocation of the patients. For one patient in each group the follow-up period was three months or less.

\section{Results}

In the untreated group the visual acuity improved two lines or more on the Snellen chart in three eyes, decreased by two lines or more in four eyes, and remained unchanged in three eyes. In the treated group vision improved in one eye, decreased in two eyes, and remained unchanged in five eyes. One patient in each group did not have a long enough period of follow-up to assess the visual acuity changes. Table II lists the visual changes of each of the patients.

None of the eyes had NVD at the time of the initial examination. During the course of the study, however, NVD developed in two of the untreated and one of the treated group. One patient in the treated group had NVE initially. This was treated focally as described above, but NVE again developed in the same eye.

Rubeosis iridis was observed only in the untreated group. Two of the patients randomly assigned to the non-treatment group initially had rubeosis. Rubeosis developed in two additional patients in the untreated group and all four progressed to neovascular glaucoma. Rubeosis was initially seen on an average of 3.25 months after the patient's reported date of onset of visual symptoms. Of the untreated patients there were five with a significant

Table I Summary of data on patients

\begin{tabular}{|c|c|c|}
\hline Patients & Untreated & Treated \\
\hline Number & I I & 9 \\
\hline Mean age (years) & $73(52-88)$ & $67(50-76)$ \\
\hline Glaucoma & 5 & 4 \\
\hline Hypertension & 5 & 2 \\
\hline Average time until & & \\
\hline examination (months) & $4 \cdot 5$ & $4 \cdot 25$ \\
\hline Average follow-up & & \\
\hline (months) & $19 \cdot 5$ & $\mathbf{I} 5$ \\
\hline Insufficient follow-up & I & I \\
\hline
\end{tabular}

Table II Changes in visual acuity

\begin{tabular}{cll}
\hline & Visual acuity & \\
\cline { 2 - 3 } Patients & Initial & Final \\
\hline Controls & & \\
I & $3 / 200$ & \\
2 & Perception of light & $20 / 300$ \\
3 & $2 / 200$ & $2 / 200$ \\
4 & $2 / 200$ & No perception of light \\
5 & $20 / 400$ & $*$ \\
6 & Perception of light & No perception of light \\
7 & Hand movements & Perception of light \\
8 & Hand movements & Hand movements \\
9 & $20 / 400$ & $20 / 70$ \\
I0 & $20 / 70$ & No perception of light \\
I I & $20 / 400$ & $20 / 200$ \\
\hline Treated & & \\
I & 1/200 & \\
2 & $20 / 400$ & Hand movements \\
3 & $3 / 200$ & $20 / 300$ \\
4 & $2 / 200$ & $20 / 200$ \\
5 & $5 / 200$ & $*$ \\
6 & $3 / 200$ & $3 / 200$ \\
7 & $6 / 200$ & $3 / 200$ \\
8 & $20 / 400$ & $2 / 200$ \\
9 & $8 / 200$ & $20 / 300$ \\
\hline
\end{tabular}

Insufficient follow-up

disappearance of capillaries at the posterior pole on initial examination as demonstrated by fundus fluorescein angiography. Of these five patients, two had rubeosis on entering the study and two developed rubeosis subsequently. These four eyes later developed neovascular glaucoma. Four of the nine patients in the treated group presented with extensive disappearance of capillaries at the posterior pole on initial examination but none went on to develop rubeosis.

\section{Discussion}

Photocoagulation has been advocated for vascular diseases of the retina including branch vein occlusion and diabetic retinopathy. The current rationale is that the destruction of hypoxic tissue by photocoagulation reduces the vascular load on the posterior pole, decreasing macular oedema and capillary leakage and allowing the remaining tissue to receive an adequate blood supply (Campbell and Wise, 1973; Theodossiadis and others, 1974). Furthermore, destruction of the pigment epithelium may promote diffusion of fluid into the choroid (Peyman, Spitznas, and Straatsma, 197I). It is also felt that the reduction in hypoxic tissue decreases the neovascular stimulus on the globe (Krill and others, I97I ; Cleasby, Hall, Fung, and Webster, 1974). 
From the analysis of our preliminary data we find no significant differences between the two groups regarding visual prognosis. Our data also currently show no definitive effect on posterior pole neovascularization.

The only effect of scatter photocoagulation found in our study was the prevention of rubeosis iridis and subsequent neovascular glaucoma. Four of the untreated group developed neovascular glaucoma although two of these patients had rubeosis when they were randomly assigned to the non-treatment group. None of the patients in the treated group has developed neovascular glaucoma. Between 8 and 48 per cent of patients with central vein occlusion are reported to develop neovascular glaucoma ultimately (Gradle, 1937; Braendstrup, 1950; Vannas and Orma, 1957; Raitta, 1965). Our preliminary data show that $360^{\circ}$ scatter treatment with xenon photocoagulation may be significant in the prevention of neovascular glaucoma.

\section{Summary}

Twenty patients with central retinal vein occlusion were randomly divided into two groups in a prospective study to evaluate the effects of xenon arc photocoagulation in central retinal vein occlusion. The patients in one group were treated with $360^{\circ}$ scatter xenon photocoagulation and the others received no treatment. The average follow-up was 18 months. There were no cases of rubeosis or neovascular glaucoma in the treated group. Two patients in the untreated group developed rubeosis with subsequent neovascular glaucoma. There was no significant difference in the visual prognosis or in fundus neovascularization between the groups.

\section{References}

BENEDICT, w. L. (1948) Arch. Ophthal., 40, 410

BRAENDSTRUP, P. (1950) Acta ophthal. (Kbh.), 35 (suppl. 7), I62

CAMPBell, J. C., and Wise, G. N. (1973) Amer. Y. Ophthal., 75, 28

Cleasby, G. W., HAll, D. L., fUng, W. F., and Webster, R. G. (1974) Mod. Probl. Ophthal. (Basel), 12, 254

DEN OTTOLANDER, G. J. H. (I 968) 'Perspectives in Ophthalmology', ed. H. E. Henkes. Excerpta Medica,

Amsterdam

DIABETIC RETINOPATHY STUDY GROUP (1976) Amer. $\mathcal{f}$. Ophthal., 81, I

dolenek, A., blatny, J., and navratil, P. (1968) Klin. Mbl. Augenheilk., 153, 403

FRANÇOIS, J., CAMBIE, E., and DE LACY, J. J. (1974) Ophthalmologica (Basel), 169, 362

- and Verbracken, H. (1974) Ann. Oculist. (Paris), 207, 553

FreYler, H., and NiCHORLIS, s. (1974) Klin. Mbl. Augenheilk., 165, 750

GITTER, K. A., COHEN, G., and BABER, B. w. (1975) Amer. J. Ophthal., 79, 578

GRADLE, H. S. (1937) Ibid., 20, II 25

HAYREH, S. S. (I97I) Ibid., 72, 998

HESSBERG, R. J. (I 944) Ibid., 27, 864

HOLMIN, N., and POLMAN, K. G. (1938) Lancet, I, 664

KLIEN, B. A. (1953) Amer. F. Ophthal., 36, 316

-

KRILL, A. E., ARCHER, D., and NEWELL, F. W. (I97I) Ibid., 85, 48

LiEBreich, R. (I855) v. Graefes Arch. Ophthal., I, 333

mehlan, J., eichler, J., and Jenssen, R. (1974) Klin. Mbl. Augenheilk., 5, 165

OOSTERHUIS, J. A., and SEDNEY, S. C. (1975) Ophthalmologica (Basel), I7I, 365

PEYMAN, G. A., SPITZNAS, M., and STRAATSMA, B. R. (1971) Invest. Ophthal., 10, 489

RAITTA, C. (1965) Acta ophthal. (Kbh.), 83 (suppl.), I I

SEDNEY, s. C. (1976) Docum. ophthal. (Den Haag), 40, r

theodossiadis, G., Charamis, J., and velissaropoulos, P. (1974) Klin. Mbl. Augenheilk., 164, 713

VAN LOON, J. A. (I96I) Ophthalmologica (Basel), 141, 467

vannas, s., and ORMa, H. (1957) Arch. Ophthal., 58, 812

- and RAITTA, C. (1972) Docum. ophthal. (Den Haag), 33, 345

Wetzig, P. C., and thatcher, D. B. (1974) Mod. Probl. Ophthal. (Basel), 12, 247

z.WENG, H. C., FAHRENBRUSh, R. C., and LitTLE, H. L. (1974) Ibid., 12, 26 I 